Georgetown University Institutional Repository http://www.library.georgetown.edu/digitalgeorgetown

The author made this article openly available online. Please tell us how this access affects you. Your story matters.

Withy, Katherine. "Authenticity and Heidegger's Antigone." Journal of the British Society for Phenomenology 45.3 (2014): 239-253.

Collection Permanent Link: http://hdl.handle.net/10822/761591

(C) Taylor \& Francis

This is an Accepted Manuscript of an article published by Taylor \& Francis in the Journal of the British Society for Phenomenology on February 13, 2015, available online:http://www.tandfonline.com/doi/abs/10.1080/00071773.2014.968993

This material is made available online with the permission of the author, and in accordance with publisher policies. No further reproduction or distribution of this copy is permitted by electronic transmission or any other means. 
This is an Accepted Manuscript of an article published by Taylor \& Francis in Journal of the British Society for Phenomenology on 13 Feb 2015, available

online: http://wwww.tandfonline.com/10.1080/00071773.2014.968993 or

http://www.tandfonline.com/eprint/3V9aheXtHh4eJNtkNcaK/full

\title{
AUTHENTICITY AND HEIDEGGER'S ANTIGONE
}

\section{Katherine Withy \\ Georgetown University}

\begin{abstract}
Sophocles' Antigone is the only individual whom Heidegger names as authentic. But the usual interpretations of Heidegger's 'authenticity' (as being-towards-death, taking responsibility for norms, world-historical creation, and a neo-Aristotelian phronessis) either do not apply to Antigone or do not capture what Heidegger finds significant about her. By working through these failures, I develop an interpretation of Heideggerian authenticity that is adequate to his Antigone. The crucial step is accurately identifying the finitude to which Antigone authentically relates: what Heidegger calls 'uncanniness' (Unheimlichkeit). I argue that uncanniness names being's presencing through self-withdrawal and that Antigone stands authentically towards this in her responsiveness to the call of being and her reticence at the end of explanation. In conclusion, I consider Sophocles' own creative act, which bequeathed to the West an understanding of being and a vision of how to relate to it authentically. I argue that Sophocles' status as a world-historical creator does not provide a competing picture of authenticity but must itself be understood as responsive and reticent.
\end{abstract}

In his 1942 lecture course on Hölderlin's poem 'The Ister', Heidegger describes Sophocles' Antigone as "“properly" unhomely' ("'eigentlich" unheimisch') (HI117) - which is to say, authentically uncanny (eigentlich unheimlich). ${ }^{1}$ This gives Antigone a rare distinction: she is the only individual whom Heidegger identifies as authentic. It is surprising, then, that interpreters of Heidegger have not paid her much mind, and in particular that she is not invoked as a standard against which interpretations of Heidegger's notion of authenticity are judged. ${ }^{2}$ In this paper, I will show that the most familiar sorts of approaches to Heidegger's authenticity do not accommodate his Antigone. From the elements of this negative claim I will build a positive account of Antigone's authenticity, and in doing so I will translate Heidegger's dense and 
opaque claims about Antigone out of the idiosyncratic vocabulary of his lecture course and into a more familiar Heideggerian vocabulary. I will argue that Antigone is authentically uncanny in that she is responsive to the call of being and reticent at the end of explanation. Heidegger's Antigone will be a surprisingly passive heroine - quite unlike the autonomous and radical Antigone whom we meet in other interpretations, and quite unlike the authentic individual described in Heidegger's earlier texts. While Heidegger's vision of Antigone may not be sufficiently grounded in the play to interest readers of Sophocles, it is Heidegger's only concrete vision of authenticity and so must be confronted by readers of Heidegger.

\section{Mortality and Ontology}

In Sophocles' play, Antigone faces punishment by death for attempting to bury her brother, Polyneices. Creon, ruler of Thebes, has forbidden proper burial and so entombs Antigone in a cave, where she commits suicide. Throughout the play, Antigone bravely faces up to her fate, saying things like 'I choose death' (Line 555, Woodruff's translation), 'Already my soul is dead' (Line 559, Woodruff's translation) and 'There's no return; I follow death, alive' (Line 810, Woodruff's translation). On the face of it, comments like these suggest that Antigone's authenticity consists in her resolute anticipation of death, which Being and Time posits as the content of authenticity. ${ }^{3}$ Although Heidegger insists that the authentic individual does not seek death or commit suicide, ${ }^{4}$ we might nonetheless see in Antigone's attitude towards her imminent death the kind of 'facing up to' mortality that Heidegger describes. However, while Heidegger acknowledges that Antigone 'faces [death] with certainty' (HI103-104), he hardly discusses her

death at all. Heidegger mentions Antigone's relationship to death only once and only in order to say that it indicates something about her relationship to being: ' $[\mathrm{H}] \mathrm{er}$ dying is, if it is anything at 
all, that which constitutes kalōs, a belonging to being' (HI104). Antigone's authenticity concerns not mortality but ontology.

Accordingly, Heidegger spends much of his analysis discussing Antigone's well-known appeal to an unwritten divine law. His key move is to ontologise this law, reading it as the law of being (HI118). The law of being trumps any civic law that Creon might enact - including the command against burying Polyneices. Of this command, Antigone says:

It was no Zeus that bade me this, Nor was it Dike, at home amongst the gods below, who ordained this law for humans, And your command seemed not so powerful to me, That it could ever override by human wit The immutable, unwritten edict divine. Not just now, nor since yesterday, but ever steadfast this prevails. And no one knows from whence it once appeared.

(Lines 450-457) (HI116)

As Heidegger reads this, Antigone tells us that there is a law of being. She tells us that we are subject to it, that we cannot override it, and that we do not know where it comes from. What is this law of being?

The 'law of being' is what Heidegger here calls 'the polis' (HI82), which he describes as both a pole and a swirl (HI81). ${ }^{5}$ These two characterisations of the polis correspond to the two senses of the 'law of being' generated by hearing the phrase as both a subjective and an objective genitive. I will return to the objective genitive and the polis as a swirl in section III. As a subjective genitive, the law of being is the polis as the pole around which 'entities, as manifest, themselves turn' (HI81/100). Entities turn around the polis in the sense that they are (or are not), and are what they are, by virtue of their relation to it. Things are intelligible to us as what they are by virtue of their relationships to other things and to human practices, concerns and 
possibilities. The totality of such meaningful relationships governs the sense that things can make, and it is what Heidegger called 'the world' in Being and Time. The polis or the world can also be understood as dikē: fittingness, or 'how things hang together'. ${ }^{6}$ To take one portion of a world or polis as an example: the 'law of the living and the law of the dead' are the complex and largely implicit sets of ways in which dead and live bodies, religious beliefs and rituals, mortality, familial obligations, climate and terrain, health and sanitation concerns, and so on, intersect and determine what it is to be dead or alive and what is to be done with dead bodies and with living bodies. Such networks of relationships - worlds - order intelligible things and provide an unwritten, hidden law for human life: a law of being.

Antigone is special for Heidegger because of her relationship to this law. In Antigone's world, the dead belong below ground and the living belong above ground. So when buried alive, Antigone must either return to the place of the living (by escaping) or become one of the dead. There is no intelligible way to remain both alive and below ground. Similarly, burying Polyneices' body is part of making Polyneices intelligible as dead and so as something that should be below ground. A dead body shows up, by the law of being, as something to be buried. Whether or not Antigone succeeds practically in burying the body, she has already succeeded ontologically if the body shows up to her as to be buried, for in this Antigone lets the dead body be what it is. She thus respects the law of being, treating entities as the entities that they are. This is an ontological piety or an ontological responsiveness. This metaphor of response in turn suggests that of a call: Polyneices' unburied body calls out 'Bury me!'. Such a call is part of what Heidegger names 'the call of being'. Antigone responds to this call by hearing it. Hearing the call of being is hearing what the situation calls for, what is fitting $(\operatorname{dik} \bar{e}) .^{7}$ 
So Antigone's distinction lies in part in the way that she allows entities to show up - that is, in the way that truth happens through her. Unlike readings of Antigone that grasp her as a moral agent confronted with a tragic conflict of multiple allegiances (usually, her allegiance to the state and her allegiance to her family or the gods), Heidegger's reading does not take Antigone to be special because of anything that she does or because of her commitment to some particular good. This would be too ontic. ${ }^{8}$ Even the Lacanian reading, on which it is Antigone's desire that marks her, is too ontic. Antigone can be understood in terms of the good (to agathon) or the beautiful (to kalon) only if these are ways of talking about the true (to alêthes). ${ }^{9}$ If Antigone remains an ethical text for Heidegger, then it is only in the sense of 'ethics' on which it coincides with ontology. ${ }^{10}$

\section{Autonomy and Creativity}

Although Heidegger does not discuss him, Creon can readily be contrasted with Antigone with respect to ontological responsiveness. As ruler, Creon thinks that he can legislate intelligibility. He is supported in this by the Chorus, which says 'It's up to you: / Make any law you want - for the dead, or for us who live' (Line 213, Woodruff's translation). But human power does not extend so far. Creon may leave a dead body above ground but he cannot make this the place where a dead body (even the body of a traitor) belongs. Similarly, he cannot - by his own authority or his action - make a tomb the appropriate place for a living body. Thus the populace eventually turns against him because he is putting the dead and the living in the wrong places. ${ }^{11}$ What Creon does not recognise is that the law of being is something 'against which nothing can avail' (HI101), 'over which human beings can neither rule nor dispose' (HI101), and which is destined or given to us (HI100). The law of being is not a human production. This is why 
Antigone calls it a 'divine' law. Creon's mistake is thus an ontological hubris: he thinks that the human being is the master of being, and in this mistakes the relationship between being and human being. Antigone points this out early on, saying (as we saw) that Creon's command is not so powerful that it can override the law of being.

Even as he attempts to override it, however, Creon does recognise the law of being. It is to this law (or to something like it (see section V)) that he appeals when he says of Antigone that 'there must be no surrender to a woman' (Line 678, Woodruff's translation), and of his son: 'Do you really think, at our age, / We should be taught by a boy like him?' (Lines 726-27, Woodruff's translation). And it is the law of being (or something like it) to which Creon eventually bows, saying 'But I cannot fight against necessity'; 'I'm afraid it's best to obey the laws, / Just as tradition has them, all one's life' (Line 1106, Lines 1113-14, Woodruff's translation). This is a deference not to religious law but to the law of intelligibility as it is embodied in tradition. Creon's accomplishment by the end of the play is that he is beginning to recognise this law.

So is Antigone authentic because, unlike Creon, she is ontologically pious? If so, then it is hard to distinguish her from her sister, Ismene. Indeed, Heidegger's discussion of the play puts only Antigone and Ismene on stage, suggesting that it is here that the real contrast lies. Ismene does not attempt to bury Polyneices because she is called to stay in her womanly place and to respect the civil law. She makes sense of herself in traditional terms as a woman and a member of the polis, and the call to be these overrides the call to bury Polyneices. ${ }^{12}$ But is this not a responsiveness to the law of being that resembles Antigone's? Antigone responds to the call to bury the body; Ismene responds to the competing call to be a woman and a good member of the 
polis. Both respect the ways in which things hang together. So what makes Antigone authentic if Ismene is not?

A second common reading of Heideggerian authenticity promises an answer. This interpretation is grounded in the chapters on conscience and guilt in Being and Time and inspired by Kant. ${ }^{13}$ On this kind of reading, Ismene follows the law of being as if it were a law of nature: she responds passively to it. To such heteronomy we could contrast acting in light of, or according to a conception of, the law. This can be understood as a commitment to the norms that govern us. Authenticity would then consist in taking responsibility for our world. Such responsibility or commitment takes what is given or found - the law of being or norms of intelligibility - and takes it up as a reason or ground for action.

Unfortunately, this reading does not fit the character of Antigone. It is part of taking responsibility for norms that we take responsibility for their legitimacy, and - since we are finite and so capable of error - this involves being willing to revise them. We must hold our norms open to revision, ready to critique them and to 'take it all back'. ${ }^{14}$ Thus the authentic individual must hold the call of being open to question. But, as Hegel stresses, Antigone does not (initially) meet this requirement. ${ }^{15}$ Antigone has an immediate relationship to norms and lacks critical distance from them. In this respect, she is just as passive as Ismene. Antigone is mired in 'ethical immediacy' and so, on this interpretation, is inauthentic.

So far, I have argued that two major interpretations of Heideggerian authenticity - facing up to death and taking responsibility for norms - do not account for Antigone's authenticity. It follows from the inadequacy of the last interpretation that a third picture of authenticity is also inadequate. In texts from the 1930s and 1940s, Heidegger thinks authenticity as world-historical creation: the questioning and transgression by which poets, thinkers and statesmen found new 
constellations of intelligibility or new worlds. ${ }^{16}$ No longer understood as mortality or revisability, finitude is grasped as a breakdown in intelligibility: the collapse of the world. ${ }^{17}$ In facing finitude, I must face up to the possibility that the constellation of intelligibility that I inhabit has ceased to work. I will have to give up myself and my world and make sense of things anew. If this is the kind of finitude that the authentic individual faces up to, then she is necessarily ontologically creative - that is, engaged in ontological transformation and innovation. ${ }^{18}$ But as we have just seen, Antigone is distinctive precisely because she does not do this. She does not manifest any ontological creativity. Ontologically, Antigone is immediate and conservative, not critical and revolutionary. It follows that she must be facing up to a different kind of finitude one for which immediacy and passivity, rather than creativity and autonomy, are appropriate.

World-historical creation is a broadly Christian conception of authenticity. It involves a transformation of self and world. A competing strain in Heidegger's thought is more Greek. Interpreters have argued that Being and Time is a rewriting of Aristotle's Nicomachean Ethics, ${ }^{19}$ and Hubert Dreyfus has developed a vision of the authentic individual that is based on Aristotle's phronimos.$^{20}$ Dreyfus' phronimos is the 'social virtuoso', who does in life what a master does in chess. Neither takes up a reflective or critical distance while acting but each responds immediately to the particular situation on the basis of established social practices in which she has been trained. What distinguishes the expert from the novice is a flexibility in and responsiveness to the situation that cannot be codified or explained. Still, we can recognise the virtuoso's action as appropriate to the situation since (unlike the creative authentic individual) the virtuoso has not left our world. Read in this way, Antigone's immediacy is a positive trait and not a flaw. Antigone skillfully responds to the call of being with the immediate agility of the expert. Dreyfus has since argued that the phronimos is an incomplete figure of authenticity, 
precisely because she is merely responsive and not creative. ${ }^{21}$ However, we can still understand the phronimos - or someone much like her - as authentic if only we notice that she is responding to a different kind of finitude. To do this, let me return to the 'law of being', this time hearing it as an objective, rather than a subjective, genitive.

\section{The Law of Being}

Recall that as a subjective genitive, 'the law of being' names the world, or the polis as a pole. It is how things hang together intelligibility, and according to it (for example) dead bodies are to be buried. Now consider: how does any world work as a world? How does the network of meaningful relationships work so that we can make sense of things? The answer to this question will be the 'law of being' in the sense of the objective genitive: the law that governs how being or intelligibility happens. Figuring out this law is Heidegger's lifelong project. One of his key insights is expressed in these lectures with the claim that the polis is a swirl [Wirbel] (HI81), which is to say that it is in the manner of 'pelein' as counterturning presencing and absencing. This amounts to saying that intelligibility or being is given to us finitely, in the sense that it is withdrawn (absences) even as it is granted (presences). This withdrawal has at least two dimensions: being (or the world) backgrounds itself and it ungrounds itself. ${ }^{22}$

First, being is backgrounding. The world worlds or the network works only when it stands as a background to our daily lives. We always take it for granted but rarely, if ever, encounter it as such. What come to the fore of lived experience are intelligible entities and not intelligibility or being itself. Intelligibility backgrounds itself so that intelligible things may show up. This is the withdrawal of the being of entities. Second, being is ungrounding. The source or 'whence' of the world is hidden from us. As Antigone tells us, we do not know where the law of 
being (qua subjective genitive, the world) comes from ('And no one knows from whence it once appeared' (Line 457, HI1 16)); but we do know that we do not make it. ${ }^{23}$ Further, the world or the polis seems to escape not only ordinary efficient causal explanation but also explanation in terms of formal and final causality. We cannot explain why intelligibility is for us in the particular constellation that it is, or why it is there for us rather than not. We cannot grasp the essence or ground of the world or polis. The reasons for this fundamental concealment are complex and contested, but they include the fact that we must always employ our current constellation of intelligibility in attempting to grasp its ground and so can never get outside of it to ground it. Being withholds its ground or is ungrounding. By thus withholding its ground, being withdraws from us. This is (or is part of) what Heidegger calls the letthe or concealment at the heart of truth, alètheia.

So the law of being (qua objective genitive) is this: being is granted to us in such a way that it withholds itself from us. Intelligibility is thus necessarily finite. There is intelligibility only on the basis of non-intelligibility, and all familiarity is ultimately grounded in a primal unfamiliarity. Specifically, being is granted in a self-withholding; it 'presenc[es] in the manner of absencing' (HI75). Such presencing in the manner of absencing is, according to Heidegger, the essence of uncanniness (Unheimlichkeit) (HI75). ${ }^{24}$ So the law of being operates on the logic of the uncanny - the play of presencing and absencing, or what we might call the play of familiarity and unfamiliarity. Intelligibility works in an uncanny way.

The human being is in turn uncanny because it is exposed to being's play of presencing and absencing. As the opening lines of Antigone's first choral ode tell us, the human being is more deinon than other entities. Heidegger translates and interprets Sophocles' 'deinon' (terrible, wonderful, strange) as 'unheimlich' ('uncanny') and 'unheimisch' ('unhomely') (HI61, 73). The 
human being is thus the most uncanny or unhomely of entities. This is so because it itself presences and absences, as the site or space in which being's own presencing and absencing takes place: 'whatever presences and absences here is itself simultaneously the open realm of all presencing and absencing' (HI75). This means (among other things) that it is the human being to whom being presences and absences. Thus being's backgrounding and ungrounding amount to a finitude in the human being's openness to being: the inaccessibility of certain dimensions of intelligibility. In turn, it follows that the human being comes to presence as what it is only by standing in some relationship to this finitude, and so to being's presencing to it by absencing from it. The challenge of human life, as Heidegger understands it, is to take up the proper stance: to stand in this play of presencing and absencing, and so in the face our finitude, in a way that is authentic.

\section{Reticent Responsiveness}

As the authentically uncanny individual, Antigone must manifest the proper relationship to being's presencing and absencing. Consider now two moments in the text that Heidegger takes to be especially telling. First, Heidegger takes Antigone's essence to be revealed by her sister Ismene when Ismene accuses Antigone of 'commenc[ing] in pursuit of' the law of being (HI99, 102). ${ }^{25}$ 'Commence' here translates $\operatorname{arche}$, which can mean beginning, point of departure, origin or rule. Heidegger wants to hear all these senses in the term: Antigone takes the law of being as her origin; she starts from it and is governed by it. Second, Heidegger claims that Antigone repeats Ismene's charge that she is pursuing the law of being a few lines later, saying:

Yet leave this to me, and to that within me that counsels the dangerous and difficult: to take up into my own essence the uncanny that here and now appears.

(Lines 95-96) 
If this is indeed a repetition, then to commence in pursuit of the law of being is to suffer (pathein, 'take up into my own essence') the deinon - that is, the uncanny. Antigone takes up the deinon as her own, appropriates it, or properly experiences it: '[ $p]$ athein does not mean the mere 'passivity' of accepting and tolerating but rather taking upon oneself, archēn de thēran [commencing in pursuit], making it through to the end, that is, properly experiencing' (HI103). 'Commencing in pursuit of' the law of being is the same as suffering the deinon, which is being authentically uncanny. Antigone thus 'properly experiences' the uncanny play of being's presencing and absencing. What does this look like?

It does not look like much at all. Recall that Antigone's authenticity is not manifest in her actions or her allegiances. In this respect, Antigone is like Kierkegaard's 'Knight of Faith', who has the right relation to finitude and infinitude but looks for all the world like a tax collector. ${ }^{26}$ However, unlike Kierkegaard's Knight of Faith, there is 'some crack' through which Antigone's authenticity 'peep[s] out'. ${ }^{27}$ This is because, unlike the creator, Antigone has not left our world but dwells in it in a special way. Her authenticity is an 'existentiell modification' of everyday life. ${ }^{28}$ It remains only to locate it.

If being presences - if intelligibility is granted - then the appropriate stance is receiving this gift: responsiveness. We have already seen that Antigone is responsive in letting Polyneices show up as to be buried. In such immediacy, she is like the virtuoso and unlike the Kantian moral agent. Since being also absences, Antigone must also relate to finitude - not her mortality, the revisability of norms, or the breakdown of her world, but the finitude of intelligibility qua the end of explanation: the backgrounding and ungrounding of being. To say that being is backgrounding is to say that the call of being, to which Antigone responds, sounds by silencing 
itself. To say that being is ungrounding is to say that the call of being also veils its source; there is no caller - no 'number' - from which the call originates. Both bring Antigone to the end of explanation, and her authenticity consists in her recognition of and respect for this limit.

It is too little noted that in a play that consistently remarks on showing and telling, Antigone does little of either. She seems dedicated to concealment and silence. In particular, Antigone has nothing to say in defense or explanation of her actions. In her confrontation with Creon, Antigone says: 'You've caught me, you can kill me. What more do you want?' (Line 497, Woodruff's translation), and 'Then what are you waiting for? More talk?' (Line 499, Woodruff's translation). Antigone's reticence makes sense in light of the backgrounding and ungrounding of being. Because the world backgrounds itself, Antigone has nothing to point to when asked why she did what she did. As an agent, she cannot lay out the structure of the Greek world and show how not leaving bodies exposed belongs to a network of shared practices and relationships of intelligibility. If someone does not get that Polyneices is to be buried - if someone cannot simply see that this is what a dead body is - then all Antigone could do is repeat herself. This is what is to be done, this is what makes sense. We bury the dead. Here, explanation comes to an end.

Antigone's appeal to the divine law, on Heidegger's ontological reading, does not provide an explanation for Antigone's actions but only marks the end of explanation. This is because the appeal to the uncanny law of being amounts to an appeal to the necessity of reticence. However, we might think that Antigone offers a clear reason for her actions in her final speech, which appeals to a law of irreplaceability:

And Polyneices, look: This is my reward

For taking care of you. I was right, but wisdom knows

I would not do it for a child, were I a mother,

Not for a husband either. Let me lie, putrefied, dead; 
I would not defy the city at such cost for their sake.

What law can I claim on my side for this choice?

I may have another husband if the first should die

And get another child from a new man if I'm a widow.

But my mother and my father lie in the land of death,

And there is no ground to grow a brother for me now.

(Lines 903-912, Woodruff's translation)

Heidegger does not discuss this passage, but a case can be made that it is consistent with his reading. The case turns on the fact that it is difficult to make sense of Antigone's appeal. Commentators have long struggled with this passage, both with regard to its peculiar style and with regard to its intelligibility. ${ }^{29}$ First, the passage seems inconsistent with Antigone's earlier appeal to the 'divine' law. Second, it seems incoherent on its own terms. Antigone appeals to the irreplaceability of Polyneices, yet he is already dead. So it is not clear why his irreplaceability should motivate his burial. Further, while it is true that Antigone cannot have another brother, it is not obvious why having another brother is of value. One would think that what is significant about irreplaceability is not that the role cannot be filled again but that it cannot be filled by this particular, singular individual. But such singularity is shared by children and husbands; it is not peculiar to brothers. So why should Antigone care about Polyneices irreplaceability if this is not a concern about singularity? To make sense of Antigone's unintelligible appeal, I suggest that we see this unintelligibility as a positive phenomenon. To give an incoherent explanation is, in effect, to affirm the impossibility of explanation. ${ }^{30}$ Attempting to speak at the end of explanation produces only nonsense; it thereby demonstrates the need for reticence and so manifests Antigone's authentic uncanniness.

Antigone could, of course, step back from her position as an agent and take up the position of the ethnographer or philosopher of culture, who can get a world in view and produce an explanation of why and how burying the dead belongs to Greek intelligibility. But while any 
such stepping back may counter being's backgrounding, it cannot address being's ungrounding character. Being is ungrounding in the sense that it veils the source of its call; we cannot explain why intelligibility takes just this form or how it came to do so. So neither Antigone nor the ethnographer - ultimately, not even the philosopher - can say or grasp where the call of being comes from or why it calls in just this way. Antigone would again find herself at the end of explanation, able to say that burying the dead is a law of being but unable to say why. Yet Antigone does not for that reason withhold her allegiance. She cannot ground the law of being or legitimate its authority but she still accepts it without questioning it. This is another dimension of Antigone's ontological piety: the pious individual does not ask the gods for their reasons or their credentials, just as Antigone does not ask the call of being for its source, justification or ground. This lack of questioning - this immediacy - is not naïveté. It is Antigone's position at the end of explanation: her facing up to finitude.

Antigone's reticence is importantly different from that of both the social virtuoso and the Knight of Faith. Kierkegaard's Abraham, as a Knight of Faith, cannot explain himself because he has left the sphere of the ethical. Even if he uses familiar words, they do not mean the same thing in his mouth that they do in his listeners' ears. ${ }^{31}$ Dreyfus' social virtuoso is reticent because her expert responsiveness cannot be explained; like the chess master, she has a knack that cannot be written down in an instruction manual. Expert responsiveness cannot be codified but can only be communicated by ostension: do it like this. While it may be the case that authentic uncanniness must be ostended, the reticence in which it partially consists is not based on the fact that an explanation cannot be put into words, that the right words are not available, or that the communication has too great a gap to bridge. It is not that words fail Antigone - that she would but cannot speak. Antigone is reticent because she has nothing to say. 
In the face of being's backgrounding and ungrounding, reasons run out. At the end of explanation, reticence is the appropriate response. With her reticence, Antigone faces up to the finitude of being and her own finitude as exposed to it. Yet she continues to respect the law of being qua world, making sense of things as the things that they are in the face of the fact that intelligibility runs out. Antigone responds to the call to bury Polyneices while being unable to explain why it must be done. Hearing and responding to the call of being while acknowledging its self-silencing is the appropriate relationship to being as uncannily presencing and absencing. In being reticent and responsive, Antigone becomes properly unhomely or authentically uncanny.

\section{The Call of Being and the Call of Tradition}

Where other readers see in Antigone a stubborn and uncompromising exercise of familial duty, Heidegger sees a reticent responsiveness to being. But Heidegger's Antigone does not thereby lack revolutionary power. Her revolutionary power comes not from creativity but from receptivity. We are not accustomed to thinking power in these terms; such a power is built on neither force nor hegemony nor autonomy. It is engaged not in creating new worlds but in revealing when the sense that things make is at odds with the intelligibility embodied in tradition, legislation or action. There is a difference between what conventions or legislation call us to do and be and what the world calls us to do and be. ${ }^{32}$ It is to this difference that feminists and civil rights activists call and have called our attention, and it is this that marks the difference between Antigone and Ismene.

Ismene (like Creon) responds not to the call of being but to the call of tradition. Traditions embody the sense that things make, and so sometimes coincide with (or amplify) the 
call of being, which is the call to let things make the sense that they do. So the call to do what is to be done is sometimes the same as the call to do what one typically does. But not always. Traditional or conventional ways of making sense of things can lose touch with what they are trying to make sense of and cease to genuinely reach things as what they are. In such cases, the call sounded is not the call of being. Ismene thoroughly conforms to such conventions; she is not open to the call of being. Her openness, she says, 'Will never aim too high, too far' (Line 68, Woodruff's translation).

Antigone can tell the difference between what conventions call her to do and to be, and what the entities themselves call her to do and be. She can distinguish the authority of being from the authority of tradition, and her allegiance is to the entities themselves before tradition. Antigone responds to the sense that things make. On the one hand, then, Antigone's 'heroism' is that of the phronimos: doing what is to be done, understood ontologically as allowing things to make sense as what they are. But by doing what is to be done, she brings into salience and personally inhabits - to her detriment (that is, her death) - the discrepancy between what being calls for and what the King calls for. So, on the other hand, Antigone is unlike the phronimos since in her case, what is to be done comes apart from what one does. Antigone is not expert in what her society expects or in what she has been trained to do. Her authenticity is not a skill; she does not follow the rules of any game. There is thus a certain novelty to Antigone's responsiveness to being.

I have already said that Antigone is not creative. Antigone does not effect any radical reconfiguration of her society's understanding of being. But her responsiveness does provide an occasion to reconsider what is and what matters. This occasion is taken up by the Chorus, which eventually recognises the legitimacy of Antigone's relationship to dead bodies. In this respect, 
Antigone's revolutionary power is more like that of Martin Luther King Jr. than that of Martin Luther. She calls attention to how we already do understand the world, which we have lost sight of - either through the tyranny of tradition, as in Ismene's case, or through a ruler's attempts to legislate intelligibility, as is the case with Creon and to some extent the Chorus. The novelty in this responsiveness to being is perhaps understood best as a retrieval, of the sort that Heidegger himself repeatedly undertakes in relation to the genuine understanding of being that has been covered over with the sediment of tradition. Antigone does not create; she reminds. In this sense, she embodies the pure impulse of phenomenology.

As a living reminder, Antigone is a conservative force. But as someone who provides this reminder, Antigone is herself revolutionary. She hears the call of being in a way that others do not, and this possibility is importantly discontinuous with participation in a tradition or obedience to other authorities of intelligibility. This way of being is radically abnormal, even if its content consists in calling our attention to the norms that, at bottom, bind us - the world in which we already dwell. Is this radical conservatism itself radically new? I conclude by returning to Hegel's reading and asking whether, in writing Antigone, Sophocles has demonstrated a creative authenticity.

\section{Sophocles' Authenticity}

On Hegel's reading, Antigone and Antigone both begin in ethical immediacy and end in selfconscious, reflective ethical life. Since Antigone and Creon both act both rightly and wrongly, by the end of the play each comes to question whether his or her action is genuinely justified. With this play, then, Greek ethical life works out its inner contradiction and transitions to a new stage in history. On Heidegger's reading, Antigone does not come to doubt and she never questions the call of being (although her position at the end of explanation does amount to being 
open to the inherent unintelligibility, and so the question-worthiness, of being as uncanny (HI80, 87)). But what is important about Antigone's questioning for Hegel is that it reflects and spurs a deep change in Greek life. Do Antigone and Antigone bring about some new stage in the development of Western Dasein for Heidegger? The answer is qualified. Yes, there is something new, but no - it is not a new stage of development.

In his first reading of the first choral ode in the play, Heidegger claims that Antigone contributes to the 'founding' of 'Greek Being and Dasein'. ${ }^{33}$ In the Ister lectures, Heidegger suggests that this founding power is concentrated in the figure of Antigone: he describes her as 'the purest poem itself' (HI119). Wherever we locate the power, the claim is that the play first opens the Greek - and so Western - understanding of being (as uncanny, and so as phusis (HI108)) and of the human being as open to being and able to stand authentically towards it. ${ }^{34}$

Heidegger sometimes implies that this opening is a development, especially when he describes Antigone as performing a 'passage through the foreign' that allows the Greeks to become 'at home' in what is their own. What is 'own' for the Greeks is the 'fire from the heavens' (HI124) or the presence of the Gods, where this means (ontologically) the rising up of being as uncanny presencing and absencing. Being exposed to being in this way is awesome and overwhelming, and the Greeks must grasp and articulate it by means of a Germanic 'clarity of presentation'. This 'foreign' allows the Greeks 'to encounter the gods in a lucidly ordered presence' (HI135). Sophocles' Antigone achieves precisely this, constituting and permitting the Greeks' grasp of themselves.

This looks like a new stage in the historical development of the Greeks - and indeed, it looks much like the stage to which Hegel thought Antigone (and other tragedies) brought the Greeks. But if the claim is that in coming to grasp themselves the Greeks founded Western 
Dasein, then this cannot be understood as a stage in a historical development. Antigone is part of a commencement or inception (Anfang) that occurred in the Greek world (HI56). A commencement is a new and discontinuous beginning; it is the inauguration of history, not a stage within it. Heidegger thinks history as the working out of one's understanding of the human being and being. Establishing this understanding is an inaugurating event that does not belong to history. Any 'previous stage', then, is always retroactively posited and is never the first in a historical series. So if Antigone sparks the Greeks' entry into history, it makes no change but does start something radically new. The vision of being and the human being that it gives us have been unfolding ever since.

Sophocles participates in the commencement and this seems to mark him as a radically creative figure. Does this change the picture of authenticity that the play gives us? For it is now significant that Antigone is a fictional character - a world-historical creation. Antigone might show us the conservative and pious dimension of authenticity, while the fact of her creation by Sophocles shows the spontaneous, creative and transgressive dimension of authenticity. The two would together make up the vision of authenticity that the play bequeaths us. But can participation in a commencement be understood as a creative act? Inaugurating Western Dasein seems too great a feat for human creativity. Indeed, Heidegger consistently attributes the commencement to being rather than the human being. So Sophocles' contribution, I suggest, lies in heeding the call of being. In this, he is responsive and reticent, just like Antigone. The two differ in the consequences of their responsiveness, because they are responsive to slightly different things and so reticent in slightly different ways.

Both Antigone and Sophocles suffer the deinon in that they stand within the play of being's uncanny presencing and absencing. Like Antigone, Sophocles is responsive to the call of 
being - but being as granted to the human being, not the being of particular entities. Thus the call that he hears is not to discover entities as the entities that they are, but to disclose being as uncannily presencing and absencing and the human being as caught in this play, authentically or inauthentically. Accordingly, Sophocles reaches the limits of explanation not because he cannot explain why entities must be uncovered in this way, but because he cannot explain why or how the commencement happens, or why or how it happens in or through him. Why is being granted to the Greeks in the way that it is? Sophocles cannot say (and nor can we), and perhaps this is why he responds to the call by writing poetry.

So Antigone and Sophocles embody the same picture of authenticity, played out at different 'depths'. This difference makes the difference between a reticent responsiveness that reminds, and a reticent responsiveness that creates. Thus in giving us Antigone, Sophocles has created a very special reminder - a reminder that first makes us into what we already are, and so gives us our essence as entities that are open to being and so who can be authentically uncanny. ${ }^{35}$

\footnotetext{
${ }^{1}$ Martin Heidegger, Hölderlin's Hymn 'The Ister', trans. William McNeill and Julia Davis (Indianapolis: Indiana University Press, 1996); Martin Heidegger, Hölderlins Hymne »Der Ister« (Frankfurt am Main: Vittorio Klostermann, 1984). I give page references in the form (HIpg) and replace the translation's 'beings' with 'entities' for 'das Seiendes'. I also transliterate all Greek words. Note that Heidegger did not discuss Antigone at all in his earlier engagement with the play (Martin Heidegger, Introduction to Metaphysics, trans. Gregory Fried and Richard Polt (New Haven: Yale University Press, 2000)). Passages from Sophocles’ Antigone are translations of Heidegger's own translations, unless otherwise noted. I have referred to Woodruff's translation (Sophocles, Antigone, trans. Paul Woodruff (Indianapolis: Hackett Publishing Company, 2001)) and to Jebb's translation (Sophocles, Antigone, trans. R.C. Jebb (London: Bristol Classical Press, 2004)).
} 
${ }^{2}$ I am not sure why interpretations of Heidegger's notion of authenticity neglect Antigone (perhaps because they focus on Being and Time?), but interpretations of the Ister lectures do so primarily because they follow Heidegger in focussing on the first choral ode of the play. Jacques Taminiaux affords Antigone only a paragraph in his 'Plato's Legacy in Heidegger's Two Readings of Antigone' (in Heidegger and Plato: Toward Dialogue, ed. Catalin Partenie and Tom Rockmore (Evanston, Illinois: Northwestern University Press, 2005)), describing her as 'simply the emblem of enduring the deinon as the only abode' (ibid., 41). Clare Pearson Geiman mentions Antigone only in passing in 'Heidegger's Antigones' (in A Companion to Heidegger's Introduction to Metaphysics, ed. Richard Polt and Gregory Fried. (New Haven: Yale University Press, 2001)). Both are more interested - and legitimately so - in the relationship between Heidegger's two readings of the first choral ode. Miguel de Beistegui's excellent analysis of the choral ode is motivated by the question of the polis and accordingly describes Antigone only as 'the very incarnation of' the homelessness described in the ode' (Heidegger \& The Political: Dystopias (New York: Routledge, 1998) 141). Gregory Fried likewise focusses on Heidegger's reading of the ode and the notions of polis and polemos (Heidegger's Polemos: From Being to Politics (New Haven: Yale University Press, 2000)). Julian Young's 'Poets and Rivers: Heidegger on Hölderlin's "Der Ister”' (in Dialogue: Canadian Philosophical Review / Revue canadienne de philosophie, 38:2 1999, 391-416) has several short and helpful sections on Antigone, but his ultimate goal is to draw out the political relevance of Heidegger's Ister lectures as a whole. I myself focus on the choral ode and its existential-ontological significance in my own Heidegger on Being Uncanny (Cambridge, MA: Harvard University Press, 2015), although I do spend some time showing how the reading that I give in this paper fits with my interpretation of the ode.

${ }^{3}$ Martin Heidegger, Being and Time, trans. J. Macquarrie and E. Robinson (San Francisco: Harper Collins, 1962). I give page numbers for the Niemeyer edition, which are included in the margins of English translations.

${ }^{4}$ Heidegger, Being and Time, op. cit., 261.

${ }^{5}$ Cf. Heidegger, ibid., 64-65.

${ }^{6}$ See for example the Parmenides lectures, delivered shortly after the Ister lectures, where dike is understood as the order that assigns and arranges, to which the human being is in turn ordered (Martin Heidegger, Parmenides, trans. André Schuwer and Richard Rojcewicz (Indianapolis: Indiana University Press, 1998), 92-93), and Introduction to Metaphysics, which contains Heidegger's earlier interpretation of Antigone: 'We translate [dikē...] as fittingness $[F u g]$. Here we understand fittingness first in the sense of joint and structure; then as arrangement, as the direction 
that the overwhelming gives to its sway; finally, as the enjoining structure, which compels fitting-in and compliance' (Martin Heidegger, Introduction to Metaphysics, trans. Gregory Fried and Richard Polt (New Haven: Yale University Press, 2000), 171).

7 '[T]o prepon is that which is fitting in the essential sense, that which is structurally articulated and ordered within the law of being' (HI101).

8 'Yet because those who seek to explain this strategy are always eager to find in Antigone's words an explanation of her actions, that is, a statement about whatever it is that causes her deeds, they are concerned only with finding some reference to entities, whether the prevailing or ancient cult of the dead, or the familial blood-relatedness. They fail to recognize that in her words, Antigone speaks of neither of these. One is still unable to see that she is not speaking of an entity at all' (HI115-116).

${ }^{9}$ Compare, for example, Heidegger's discussions of Plato on to agathon and to kalon at HI87ff and in Martin Heidegger, The Essence of Truth: On Plato's Cave Allegory and Theaetetus, trans. Ted Sadler (New York: Continuum, 2002).

${ }^{10}$ Martin Heidegger, 'Letter on Humanism', trans. Frank A. Capuzzi, in Pathmarks, ed. William McNeill (Cambridge: Cambridge University Press, 1988), 271.

${ }^{11}$ The seer Tiresias says: 'You took one who dwells above and tossed her below, / You rejected a living soul and peopled a tomb with her. / And you took one who belongs down there and kept him here, / Untouched by the gods, unburied, unholy, a corpse exposed' (Lines 1068-1071). The chorus agrees: 'Let the girl go. Free her from underground. / And build a tomb for the boy who lies exposed' (Lines 1100-1101) (Woodruff's translations, op. cit.).

${ }^{12}$ Since women traditionally buried the dead, the call to be a woman overrides the call to bury in a complicated way. It is filtered through the (gendered) civic call: 'We are women and we do not fight with men. / We're subject to them because they're stronger, / And we must obey this order, even if it hurts us more' (Lines 62-64, Woodruff's translation, op. cit.).

${ }^{13}$ See Heidegger, Being and Time, op. cit., Division 2, Chapter II. This reading of authenticity is based on John Haugeland's work (see, e.g., John Haugeland, 'Truth and Finitude: Heidegger's Transcendental Existentialism', in Heidegger, Authenticity and Modernity: Essays in Honor of Hubert L. Dreyfus, vol. 1, ed. Mark Wrathall and Jeff Malpas (Cambridge: The MIT Press, 2000) 43-78). It is developed and articulated in, for example, Rebecca Kukla, 
'The Ontology and Temporality of Conscience', in Continental Philosophy Review, 2002, 35: 1-34; and Steven Crowell, 'Subjectivity: Locating the First-Person in Being and Time' in Inquiry, 2001, 44: 433-54.

${ }^{14}$ Heidegger, Being and Time, op. cit., 308. As Haugeland puts it: 'Taking responsibility for something is not only taking it as something that matters, but also not taking it for granted' (Haugeland, op. cit., 72).

${ }^{15}$ See G.W.F. Hegel, The Phenomenology of Spirit, trans. A.V. Miller (New York: Oxford University Press, 1997), especially §429-§476. As Kukla puts it, ‘[s]he could not actually recognize their [sc. norms’] claims, because, as transgression was not a disclosed possibility for her, she could not step back from them so as to see them as making a claim upon her, which she had a responsibility to live up to in virtue of her commitment to their legitimacy' (Kukla, op. cit., 31 footnote 5)). However, for a compelling reading of Antigone as autonomous in Kant's sense, see David N. McNeill, ‘Antigone’s Autonomy’ in Inquiry, 2011, vol. 54, no. 5, 411-441.

${ }^{16}$ For instance, Heidegger employs this view of authenticity in his interpretation of the first choral ode from Antigone in Introduction to Metaphysics, op. cit..

${ }^{17}$ For readings of Being and Time's discussion of death along these lines, see Haugeland (op. cit.) and Carol J. White, Time and Death: Heidegger's Analysis of Finitude (Burlington, Vermont: Ashgate Publishing, 2005).

${ }^{18}$ I intend this characterisation to cover even an ontological creativity that does not produce pure novelty but which makes central previously 'marginal' practices.

${ }^{19}$ Notably and persuasively, Theodore Kisiel, The Genesis of Heidegger's Being and Time (Berkeley: University of California Press, 1995). See also Robert Bernasconi, 'Heidegger's Destruction of Phronesis' (in The Southern Journal of Philosophy, 28, Supplement, 1989, ), Walter Brogan, ‘A Response to Robert Bernasconi’s “Heidegger’s Destruction of Phronesis"' (in The Southern Journal of Philosophy, 28, Supplement, 1989, 127-147), Walter Brogan, Heidegger and Aristotle: The Twofoldness of Being (Albany, New York: State University of New York Press, 2005) and Franco Volpi, 'Dasein as praxis: the Heideggerian assimilation and radicalization of the practical philosophy of Aristotle' (in Martin Heidegger: Critical Assessments, Volume II: History of Philosophy, ed. Christopher Macann (New York: Routledge, 1992) 90-129).

${ }^{20}$ For a clear (albeit retrospective) account of this view, see Hubert L. Dreyfus, 'Could anything be more intelligible than everyday intelligibility? Reinterpreting division I of Being and Time in light of division II', in Appropriating Heidegger, ed. James E. Faulconer and Mark A. Wrathall (New York: Cambridge University Press, 2000) 155-174.

${ }^{21}$ Dreyfus, ibid. . 
22 There is also a third dimension of being's withdrawal, which Heidegger calls the Mystery (Geheimnis). For an early statement of the difference and relationship between lèthē and the Mystery, see Martin Heidegger. 'On the Essence of Truth', trans. John Sallis, in Pathmarks, ed. William McNeill (Cambridge: Cambridge University Press, 1998).

23 'That which is determinative, that which determines Antigone in her being, is beyond the upper and the lower gods. And yet it is something that pervasively attunes human beings as human beings. Yet it is no mere human ordinance, for such has no power over divine edict and thus falls emphatically below what prevails even beyond the gods. At no time can what is determinative here be encountered anywhere as something first posited on a particular occasion, and yet it has already appeared before all else, without anyone being able to name a particular entity from which it has sprung forth' (HI116-117).

${ }^{24}$ What Heidegger means by 'uncanny' and 'uncanniness' is thus quite different from what most people mean: the creepy or the odd and unlikely. Heidegger's uncanniness comes close to Freud's uncanny qua the return of the repressed - the previously familiar but since rejected, returned to the conscious mind (Sigmund Freud, 'The Uncanny', trans. James Strachey, in The Standard Edition of the Complete Psychological Works of Sigmund Freud. Volume XVII (1917-1919): An Infantile Neurosis and Other Works (London: Vintage, 2001)). For this reason, it also somewhat resembles the uncanny found in recent literary theory: that which surpasses the familiar and ambiguously crosses over into the strange. But there are subtle and important differences that remain - both in the structure of Heidegger's concept and in its ontological status. For a full exploration of this, see my Heidegger on Being Uncanny, op. cit.

${ }^{25}$ Translating this line is difficult and Heidegger discusses it at some length. The line reads: 'archēn de thēran ou prepei tamēchana' (Line 92). Heidegger translates: 'Yet to commence in pursuit of that remains unfitting, against which nothing can avail'. Woodruff translates: 'But it's the highest wrong to chase after what's impossible' (op. cit.); Jebb translates: 'A hopeless quest should not be made at all' (op. cit.).

${ }^{26}$ Søren Kierkegaard, Fear and Trembling, trans. Alastair Hannay (New York: Penguin Books, 2006), 42.

${ }^{27}$ Kierkegaard, ibid., 42. 
${ }^{28}$ Compare: 'Authentic Being-one's-Self does not rest upon an exceptional condition of the subject, a condition that has been detached from the "they"; it is rather an existentiell modification of the "they" - of the "they" as an essential existentiale' (Heidegger, Being and Time, op. cit., 130).

${ }^{29}$ Jebb reports that 'Few problems of Greek tragedy have been more discussed than the question whether these vv., or some of them, are spurious'. For his own part, he says: 'I confess that, after long thought I cannot bring myself to believe that Soph. wrote 905-912' (op. cit., 164). For a full discussion, see the Appendix to Jebb's translation.

${ }^{30}$ I am grateful to an audience member at a session of The International Association for Philosophy and Literature (IAPL) Annual Conference in 2012, at which I delivered an early draft of this paper, for suggesting this sort of reading.

${ }^{31}$ Kierkegaard, op. cit.. See Problema III.

${ }^{32}$ Heidegger nowhere makes this distinction explicitly, but he implies it in Being and Time: 'Dasein is inclined to fall back upon its world [...] but also [...] Dasein simultaneously falls prey to the tradition. [...] When tradition thus becomes master, it does so in such a way that what it "transmits" is made so inaccessible, proximally and for the most part, that it rather becomes concealed. Tradition takes what has come down to us and delivers it over to selfevidence; it blocks our access to those primordial "sources" from which the categories and concepts handed down to us have been in part quite genuinely drawn' (Heidegger, Being and Time, op. cit., 21).

${ }^{33}$ Heidegger claims that tragedy is 'the poetry in which Greek Being and Dasein were authentically founded', and that the first choral ode is 'a poetic projection of Being-human among the Greeks' and 'provides the authentic Greek definition of humanity' (Heidegger, Introduction to Metaphysics, op. cit., 154, 156, and 161).

${ }^{34}$ The same conclusion can be reached through the argument that, on Heidegger's reading of the first choral ode, the chorus - which Heidegger argues speaks with the voice of Sophocles - expels the human being from the hearth, thereby making it uncanny (HI92 et passim).

${ }^{35}$ I thank audiences at the following for their helpful comments and questions: The Southwest Seminar in Continental Philosophy (2013, Texas A\&M University); The Australasian Society for Continental Philosophy Annual Conference (2012, Auckland University); The International Association for Philosophy and Literature Annual Conference (2012, Tallinn University); Chicago Heideggerians' and Husserlians’ Reunion Colloquium (2012, The University of Chicago); International Society for Phenomenological Studies (2012, Maine). 